\title{
On the border between culture and religion \\ Public policies for Afro-Brazilian religions in Brazil
}

Daniela Cordovil

\section{Abstract}

This paper aims to discuss some of the recent questions concerning the promotion of public policies for Afro-Brazilian religions. To access to these policies, these groups have organized over the last few decades in the form of civil society associations and their leaders have attended many ministerial board meetings and committees. Because of this engagement, Afro-Brazilian religions were classified as "traditional terreiro peoples" and more recently received the label of "traditional peoples and communities of African origin." The paper analyses the various arguments underpinning the discursive construction of Afro-Brazilian religions as representatives of a black cultural heritage in Brazil. Keywords: Afro-Brazilian Religions. Religions of African Origin. Public Policies. Black People.

\section{Resumo}

Este texto tem como objetivo problematizar algumas questões recentes a respeito da promoção de políticas públicas para afrorreligiosos no Brasil. Para obter acesso a estas políticas, os afro-religiosos tem se organizado nas últimas décadas sob a forma de associações civis e suas lideranças participam de diversos conselhos e comitês ministeriais. Por conta deste engajamento, os afro-religiosos foram classificados como "povos tradicionais de terreiro" e, mais recentemente, receberam o rótulo de "povos e comunidades tradicionais de matriz africana". O texto analisa os diferentes argumentos que embasam a construção discursiva das religiões de matriz africana como representantes de uma herança cultural negra no Brasil.

Palavras-chave: Religiões de matriz africana. Religiões afro-brasileiras. Políticas públicas. Negro. 


\section{On the border between culture and religion}

Public policies for Afro-Brazilian religions in Brazil

Daniela Cordovil

\section{Introduction}

The first decade of the twentieth century marked a unique historical moment for people in Brazil practicing religions whose wisdom was brought by black Africans. These religions - which today appear in ministerial decrees under the rubric of Povos Tradicionais de Matriz Africana1- had been considered a problem for Brazilian society for many decades. Persecuted by the police, they appeared on the police pages of newspapers throughout Brazil accused of sorcery, magic and charlatanism. After more than a century of such persecutions, the practitioners of this religious form are today considered holders of rights, based on their role as bearers of traditional knowledge. The present text explores the political trajectory and the semantic shifts necessary to this transformation.

The persecution of Afro-Brazilian religions, documented from the First Republic onwards, contrasts with the treatment of Protestant Churches during this same period when they began to arrive in Brazil. The first republican constitution, promulgated in 1891, formally established the secular State, granting freedom of worship to non-Catholic religions as long as these were practiced in the domestic sphere.

However, this guarantee was not extended to those who practiced religions influenced by African and indigenous knowledge. In Bahia at the end of the nineteenth century, Raimundo Nina Rodrigues (1862-1906) was the first researcher to become interested in the religiosity and culture of black people. He documented newspaper reports from the era telling of police persecutions and raids on terreiros: ${ }^{2}$

\footnotetext{
1 Traditional People and Communities of African Origin.

2 Terreiro, literally yard or grounds, is the term used for the religious spaces used in candomblé, also sometimes referred to as temples or houses.
} 
In Africa, these cults comprise a veritable State religion, in whose name the chiefs govern. Hence they are guaranteed by government and custom alike. In Brazil, in Bahia, on the contrary, they are deemed sorcery practices, unprotected by laws, condemned by the dominant religion and by the disdain, very often only apparent, it's true to say, of the influential classes, who despite everything fear them [...] Today, with the end of slavery, they have become subject to the tyranny and whim of the police, no more enlightened than the former masters, and to the remonstrations of the general public, which, though believing itself to possess a strong and cultured spirit, constantly reveals its supine ignorance of sociological phenomenon. (Rodrigues 2004: 269).

It was not only in Bahia that Afro-Brazilian religions suffered the persecutions and incomprehension of government leaders and intellectuals. In Pará during this same period reports about charlatanism and false shamans also filled the local newspapers and intrigued intellectuals of the day, as the historian Aldrin Figueiredo documents:

These stories - which shed light on both the relentless persecution of shamans and the no less untiring action of the healers in maintaining and defending their religious practices - constitute just one corner of the issue, towards which many other stories converge. The persecution of shamans was not confined to the police: it involved newspaper offices, the city health committee, journalistic opinion, and medical discourse. (Figueiredo 2008: 130).

As well as the stigma propagated by the press, public administrators and social elites, everything of African and indigenous origin aroused fears among intellectuals concerned with elaborating an ideology of national identity. Based on an ideological interpretation of Darwin's theory of evolution, black and aboriginal peoples were believed to be among the least evolved, a kind of living fossil, images of humanity's pre-history (Scwarcz 1993). In Brazil intellectuals became increasingly concerned with how to transform a territory largely populated by black slaves and wild Indians into a modern nation along European lines.

\section{The terreiros and Africa in Brazil}

Despite the police persecutions, some scholars made contacts with the terreiros, initially in order to civilize the people and improve their health, 
and later to explore a scientific perspective. The first such scholar was Nina Rodrigues, who at the end of the nineteenth century became the first researcher to observe rituals in situ in the Gantois terreiro in Salvador. The author published a vast opus, re-examined in the 1930 s by Arthur Ramos, his self-proclaimed intellectual heir (Corrêa 1998). In parallel to the research of Arthur Ramos and his disciple Edson Carneiro, both of whom studied in Bahia, Gilberto Freyre was also interested in Afro-Brazilian religions, seeking to give them political and academic legitimacy through the realization of Afro-Brazilian Congresses.

As part of this process of accepting Afro-Brazilian religions, which began in the Northeast in the 1930s, there was a selective appropriation by intellectuals of particular cult houses and types of liturgy, classifying those that did not fit into the created models as 'degenerate' or 'impure.' For decades those researchers contributed with their works and political activism to creating the myth of 'Brazilian Africa,' legitimately represented by the terreiros considered 'pure,' where traditions were supposedly better preserved.

The candomblé terreiros were perceived as pieces of Africa in Brazil, where the black and impoverished population made up of descendants of slaves living on the outskirts of cities could once again experience their African identity. Or, as Roger Bastide put it, describing the moment of trance:

They are no longer seamstresses, cooks, washerwomen who whirl to the sound of drums in the Bahian nights; there is Omolu covered in straw, Xangô dressed in red and white; Iemanjá combing her seaweed hair. Their faces transform into masks, losing the wrinkles of everyday work, the stigmas of day-to-day life full of worry and misery vanishing; warrior Ogun fights in the heat of fury, Oxum is all carnal voluptuousness. For a moment Africa and Brazil merged, the Ocean abolished, the time of slavery erased. (Bastide 2001: 39).

Beatriz Góis Dantas (1987) deconstructed this idea of Nago purity, supposedly linked to the idea of Sudanese or Yoruban cultural heritage. The author shows the ideological biases and political interests behind the construction of some cults to be more traditional than others within the Afro-Brazilian religions. The author shows how the notion of 'African purity,' normally associated with the 'Nago' candomble cults of Bahia, is a native category, utilized by the religious leaders themselves as a form of legitimizing their practices, and how its assimilation by the anthropological literature contributed to this 
use insofar as the terreiros considered 'pure' by anthropologists (who in some cases supported them publicly by acting as ogãs) obtained more recognition from society as a legitimate religion, in contrast to the caboclo candomblé, seen as 'magic' or 'witchcraft.' The author presents an interesting interpretation for the excessive valorisation of Africa by Brazilian intellectuals:

In fact it is the passage of the African, a foreigner of different and exotic customs, the Negro, a black-skinned Brazilian, that creates problems. Perhaps it was the difficulty of making this passage, with the ideological premises underlying it, that led authors like Nina Rodrigues and Arthur Ramos to use an apparently contradictory double schema: the evolutionist perspective, which demanded the simultaneous dilution of the black in the white as a condition of progress - and the exaltation of primitive African purity. (Dantas 1988:149).

As a critique of the proposal of Dantas and of other studies based on the work The Invention of Tradition, edited by Eric Hobsbawm and Terence Ranger (1992), Matory (1999) argues that the African nations recreated in the New World are part of a transnational process of discourse production whose main protagonist is a black literate elite constituted in a transnational flux:

The Africa that lives in the black Americas should not be measured in terms of a more or less pure survival of a primordial 'elsewhere.' The Africa that lives in the Americas is a strategic mobilization of a circum-Atlantic cultural repertoire spanning five hundred years. In sum, much of what is called cultural or collective 'memory' in the African diaspora, and in every nation, occurs in contexts of power, negotiation and recreation. This point is usually neglected by the discourse of the 'invention of tradition,' negating the agency of the oppressed. (Matory 1999: 68)

In parallel to the search for Africa and the African purity that took place in the Northeast, Umbanda emerged in the Southeast of Brazil, an AfroBrazilian religion created through the syncretism between Banto traditions, Catholicism and Kardecist spiritism. In Umbanda, elements taken to be authentically African, such as animal sacrifice and long periods of initiatory reclusion, were minimized as part of the religion's adaptation to the modern context (Ortiz 1978).

In the 1970s, after the remarkable expansion of Umbanda in Brazil's Central-South region, this variant of Afro-Brazilian religiosity entered into 
decline in relation to candomblé, previously considered savage or barbaric. Reginaldo Prandi (2005) points to the expansion of tropicália and the Bahian counter-culture in the Central-South of Brazil as a factor that unleashed the movement of a return to origins among Umbanda's religious leaders.

This period saw the emergence of major names in Brazilian popular music, who found a source of inspiration in the Afro-Brazilian religions for composing their image of Brazilianness. Through Brazilian popular music and the work of singers like Clara Nunes, Afro-Brazilian religions began to be seen positively by the country (Bakke 2007). Orishas populated the national imagination, even though in practice the vast majority of terreiros found themselves under suspicion and surveillance during the military dictatorship.

In the 1980 and 9os, Afro-Brazilian religions began to expand geographically beyond the national borders, reaching Europe and the Southern Cone countries (Oro 1995). This expansion was accompanied by their transition from ethnic to universalist religions, whose presence in the urban environment closely accompanied social and technological changes, incorporating academic writing and research as forms of transmitting religious knowledge and developing a variety of strategies to adapt their liturgies to the everyday life of metropolitan areas:

It is in this game of representations between candomblé, a religion of ethnic origin, and the metropolis, increasingly multi-ethnic and pluri-cultural, that the former, curiously, would extol its vocation as a religion of universal conversion, although it remains a polytheist religion strongly influenced by magical thought. (Silva 1995: 290)

Researchers also observed that these religions did not just expand rapidly among black-skinned people:

The social base of candomble changed and changed hugely. A large number, perhaps the majority, are poor people who find it very difficult to meet the financial expenses incurred by the exuberance and complexity of the rites [...] But the middle class, white and schooled, is very often competing with poor black people, who obviously, as Afro-Descendants, frequently believe themselves to be the legitimate owners of the tradition of the Orishas. (Prandi 2005: 246-7).

For the scholars cited above, the expansion of Afro-Brazilian religions 
through the metropolises of the Central-South of Brazil and abroad distanced them from their ethnic character as family-based religions, worshipped by descendants of African populations brought to Brazil during slavery. In parallel to the expansion of these Afro-Brazilian religions to a public beyond the black descendants of slaves, the political movement of strengthening minorities gained strength in Brazil, from which Afro-Brazilian religions would benefit politically.

\section{Debate on the race issue and public policies for terreiros}

After the Third World Conference against Racism, Racial Discrimination, Xenophobia and Related Intolerance, which took place in Durban, South Africa, in 2001, the Brazilian State developed an institutional policy for fighting racism (Lima 2010). Projects appeared initially, followed later by public bodies responsible for the implementation of coordinated reparation policies targeted at Afro-Descendants.

The main impacts of the Durban Conference can be felt in strategic sectors like healthcare and education. In 2003 SEPPIR (Special Secretariat for Racial Equality Promotion Policies) was created and Law 10.639 promulgated, which made teaching Afro-Brazilian History and Culture compulsory in schools. In the following years the discussions in the health field progressed and in 2009 the National Health Policy for the Black Population was implemented, increasingly recognizing the healthcare and care practices realized in terreiros as a legitimate form of knowledge (Alves \& Seminnoti 2009, Silva 2007). The population covered by these policies includes all those declaring themselves preto and pardo (black and brown) in the IBGE census, $45 \%$ of the Brazilian population according to data from 2000. Among the policy proposals are:

Promoting recognition of popular healthcare knowledge and practices, including those preserved by religions of African origin. (Brazil 2010).

In 2010, also through the mediation of SEPPIR and the black movement, the Racial Equality Statute was promulgated (Law 12.288), with Chapter 3 dedicated to combatting the religious intolerance shown against AfroBrazilian religions, under the title of "Freedom of conscience and belief and the free practice of religious worship." 
The main changes in how the Brazilian state responds to the issue of racism can be linked to three factors: the pressure of the black movement at local level, the inclusion of these themes on the international agenda and the greater participation of leaders from the black movement within the government during the Lula presidencies (2002-2010).

The contemporary political activism of leaders of Afro-Brazilian religions involves an appropriation of the discourse of multiculturalism and the new social movements in order to found a basis for strategic action in search of power and legitimacy that forms part of the very trajectory of Afro-Brazilian religions.

Thus the ideals that ground the political demands of leaders of AfroBrazilian religions, like religious freedom, gender equality, sexual and reproductive rights and the human right to health, food and territory, pervade a global political discourse guided by the logic of universal human rights.

Although these guarantees of rights for Afro-Brazilian religions emerged in direct connection to the race issue, a debate specific to Afro-Brazilian religions has developed in recent years is the field of food security. The inclusion of Afro-Brazilian religions in this debate has involved a sui generis political trajectory.

Over recent decades minority groups have become increasingly politicized, engaging in various fights for public policies. In Brazil many historically marginalized populations first started to mobilize in the rural world through the fight for land and the defence of the environment. It was primarily through these rural campaigns that the political category of 'traditional peoples' emerged in which Afro-Brazilian religions would later be included.

From the 1980s, fights for land regularization revealed the existence of groups in Brazilian society that make collective usage of land through uses and customs that evade market logic, insofar as they are based on criteria of belonging like kinship, culture and religiosity (Almeida 2002). Among these groups we can cite indigenous and quilombola peoples, whose right to land is guaranteed in the text of the 1988 Constitution, and a series of populations who also make collective use of land, but whose right is not explicitly mentioned in the Constitution. It was these populations that began to be referred to by the encompassing label of "traditional populations". As Barreto Filho writes: 
The notion of 'traditional population' expresses a set of collective cultural values related to the environment - perceptions, values and structures of meaning that guide and lie at the origin of certain environmental policies. A term embodied in our current dialogue with the natural world and in the lexicon of government agencies responsible for the environment, the notion produces effects in the symbolic disputes constituting the micropolitics of the campaigns pursued by rural workers for access to the means of production and in the political processes that influence territorial rights (Barreto Filho 2006: 110)

The demands of traditional peoples for their territories to be guaranteed by law had a direct impact on the construction of Brazilian environmental legislation in terms of human occupation of environmental conservation areas. It is impossible to understand the historical trajectory of the populations that formed the groups marginalized in the formation of the Brazilian State without paying attention to their political struggles, constructed through traditional relations with the territory, as part of what Little (2010) calls political ecology.

With the beginning of debates and construction of public policies relating to the Zero Hunger program run by the Ministry of Social Development and Combatting Hunger (MDS), the category of traditional peoples dilated further, providing space for a range of groups characterized by a distinct occupation of space and by cultural practices different from the rest of national society. The majority of the groups today labelled traditional populations share in common the demand for their territories to be recognized by the Brazilian State. These claims began with indigenous societies (Oliveira 1998) and currently extend to quilombola peoples (O’Dwier 2005) and the so-called extractivist populations of Amazonia, like the river dwellers (ribeirinhos), andiroba extractors (andirobeiras) and others (Barreto Filho 2006).

These discussions eventually resulted in the promulgation of Decree 6.040/2007, which established the National Policy for Traditional Peoples and Communities. The policy was created through workshops with representatives of associations from these communities. In the first workshop held to debate the policy, hosted in the town of Luiziânia, Distrito Federal, in 2006, the leaders attending classified themselves into 15 categories of identity: sertão dwellers (sertanejos), rubber tappers, Bahian collective pasture (fundo de pasto) communities, quilombolas, Amazonian agroextractivists, 
rural inhabitants of Paraná (faxinais), artisanal fishing communities, terreiro peoples, Roma, Pomeranians, indigenous peoples, pantanal dwellers (pantaneiros), coconut breakers, rural coastal populations (caiçaras) and inhabitants of the cerrado (geraizeiros) (Brazil 2006).

Using the results of this and other workshops held over the course of the year, the ministerial team elaborated the National Sustainable Development Policy for Traditional Peoples and Communities, with an emphasis on issues such as sustainable development, territory, food security, and the right to maintain cultural and religious specificity. Religion is explicitly mentioned in three of the plan's articles, including the guarantee to combat religious intolerance.

In Decree 6.040/2007, traditional populations are conceived as follows:

Culturally differentiated groups that recognize themselves as such, which possess their own forms of social organization, occupy and use territories and natural resources as a condition for their cultural, social, religious, ancestral and economic reproduction, utilizing knowledge, innovations and practices generated and transmitted by tradition.

Following implementation of the policy, which included the participation of leaders of Afro-Brazilian religions and specialists in Afro-Brazilian religion linked to the academy, the MDS, in partnership with Special Secretariat for the Promotion of Racial Equality, mapped the terreiros, firstly in Salvador, and later implemented the Socioeconomic and Cultural Survey of Terreiro Peoples and Communities, which encompassed four Brazilian state capitals - Belém, Belo Horizonte, Porto Alegre and Recife - and the results of which were published under the title Alimento: Direito Sagrado (Food: a Sacred Right, Brazil 2011). The book contains articles written by researchers along with pais de santo and mães de santo3, in which the Afro-Brazilian Religion background to the food security issue is debated. The mapping work has already registered more than 5,00o terreiros across the national territory. This register is used in the distribution of food baskets to the terreiros, organized in civil associations.

The inclusion of the Povos e Comunidades de Terreiro ${ }^{4}$ in the National Policy for Traditional Peoples and Communities, created by Decree 6.070 of

\footnotetext{
3 Father or Mother of Saint is the name used to call the priests and priestesses of Afro-Brazilian religion.

4 People and Communities of terreiros, was the name used by leaders of Afro-Brazilian religion to classify themselves in the policy.
} 
2007, signified their addition to the list of sectors of national society with non-hegemonic forms of social organization and territorial occupation. Through this decree, these peoples are legally defined as culturally differentiated groups whose traditional forms of occupying their territory through cultural, social and religious practices must be respected and supported by the Brazilian State.

The vast majority of groups included in this category are situated outside the environment of the big cities - indigenous and quilombola peoples, rubber tappers, andiroba extractors (andirobeiras), babassu coconut breakers, etc. - and whose main axis of identity construction is the occupation of a territory and a particular form of social and economic reproduction of the group. In the case of Afro-Brazilian religions, whose terreiros are geographically situated on the periphery of the big cities, distinct cultural and religious practices exist and the fight for land is not the main demand.

Located on the private properties of their leaders, only a small portion of the terreiros were registered by IPHAN (National Institute of Historic and Artistic Heritage), assuring the religious community definitive ownership of the property. The reality faced by most terreiros in Brazil is the fragile legal basis for ownership of the property where the community is based. Many communities of Afro-Brazilian religions disperse after the death of their leader since the latter's biological family inherits the property rather than the religious community.

Some terreiros were founded in properties located in devalorised peripheral areas of cities. After decades of urban expansion, these terreiros became embedded in an urban zone whose land value is continually increasing. In some cases priests acquire properties in more distant areas, leaving the previous locations merely as their residence and the base of operations for the terreiro's civil association. Religious intolerance is also identified as one of the motives for the search for locations further away. As terreiro leaders recount in the book Alimento, Direito Sagrado:

The difficulties in access to these communities were reinforced by the process of ethnic/religious cleansing pursued by Neo-Pentecostals, who ended up forcing various communities based on the urban outskirts of Belém to relocate to even more outlying regions (Nalva \& Tayandô 2011: 76) 
Terreiros that were previously located in Belo Horizonte moved to more precarious locations, either to escape urban violence and religious prejudice, or because they had no alternative since the price of the property in the capital had become extremely expensive due to land speculation (Arabomi \& Silva 2011: 84)

Traditional use of the territory derives from a particular form of spirituality, yet even without a territory this spirituality can continue to be practiced. The foundation of a terreiro sacralizes space through specific liturgical processes. However, this process is not irreversible: the reality of the urban environment reveals a large number of terreiros that constantly shift location due to economic pressures, political questions linked to the transmission of leadership or to escape from religious persecutions.

Pais and Mães de Santo are comfortable with the label of "traditional populations" since they recognize that religion promotes a distinct form of social organization and spatial occupation. Indeed some leaders have shown a need for their religious communities to increasingly adopt the old candomblé concept of the roça (plantation/field). Roças are large spaces, far from the city centres, where many filhos de santo settle to live and sometimes breed animals for use in the liturgies.

The food security policy promoted by the MDS in the terreiros emphasizes the redistribution practiced by religious communities. One characteristic of terreiro communities is that they always function as a space for the distribution and redistribution of goods and services. To enable the operation of a set of liturgical obligations, the povo do santo5 need to develop various forms of knowledge and a series of techniques towards this organization. These skills include embroiderers, tailors, specialists in leatherwork and woodwork to make the musical and percussion instruments, and specialists in metalwork who produce liturgical objects. This network of products and forms of knowledge is what José Jorge Carvalho (2011) has called an economy of ashe:

The objects and foods with ashe - in other words, objects imbued with a vital positive energy that will be offered to the entities with which the initiates will enter into contact - are only encountered in the economic and social network surrounding the povo de santo. It is this living network, interpersonalized and currently expanding, that I denominate the economy of ashe (Carvalho 2011: 38)

5 People of Saint was a name used to call all those belongs of Afro-Brazilian religions. 
The form of producing and consuming foods in the terreiros has indicated a more sustainable economy than the goods produced within the capitalist framework. The animals offered to the gods and that are also consumed by human beings in festivals and rituals cannot be obtained via the large-scale food distribution network: they must be created in open spaces close to nature.

On the other hand, the urban expansion that also negatively affects terreiro communities has made it impossible for these groups to practice their traditional forms of economic reproduction. The debate stimulated by the MDS's food security policy has allowed Afro-Brazilian religions to reflect on their demands, leading them to pressurize the State for land regularization policies relating to their spaces of worship, including incentives for small-scale food production.

\section{Povos e Comunidades Tradicionais de Matriz Africana}

The specificity of Afro-Brazilian religions within the list of groups targeted by public policies for traditional peoples and the engagement of their leaders led to the policy for these groups becoming independent from the other groups.

In 2012, the change of name from Povos e Comunidades Tradicionais de Terreiro to Povos e Comunidades Tradicionais de Matriz Africana was debated. Officials from SEPPIR explained this decision to Pais and Mães de Santo with the argument that the change would facilitate the advance of the policies. With the consent of the leaders of Afro-Brazilian religions, a meeting was held in Brasília, in August 2012, to propose the setting up of a workgroup to elaborate a specific policy for Afro-Brazilian religions, or traditional people and communities of African origin as they are now called.

In the text publicizing this meeting, found on the MDS website, the words 'religion' and 'terreiro' are not mentioned once. The only elements revealing the religious affiliation of those present are the turbans and white clothing, which can be seen in the photos of the meeting. Concerning the Povos e Comunidades Tradicionais de Matriz Africana, the National Secretariat of Food Security and Combatting Hunger emphasized:

Diet is one of the biggest problems. These are vulnerable low-income communities. This is the target public for the public policies. (Ministry of Social Development and Combatting Hunger 2012). 
January $29^{\text {th }} 2013$ saw the launch of the National Sustainable Development Plan for Peoples and Communities of African Origin, with an emphasis on development, including in the area of production, and on guaranteeing rights. The plan is intended to enable the access Afro-Brazilian religions organized in civil associations to projects and initiatives funded by public money coming from various ministries, something already happening at a smaller scale. The plan defines Povos e Comunidades Tradicionais de Matriz Africana as:

Population groups that are organized on the basis of the civilizatory values and the cosmovision brought to the country in the context of the slave system, and which enables the continuation of African civilization in Brazil, forming their own territories characterized by community living, care and provision of services to the community (Brazil 2013).

The public policies for Afro-Brazilian religions are an important form of social inclusion of these groups and have the effect of a historical compensation for the violence perpetrated against Africans sold as slaves in Brazil and against their religious beliefs. These policies reach Afro-Brazilian religions through the recognition of their practices as a cultural heritage distinct from national society.

This political concept demonstrates that those planning public policies see the terreiros as locations frequented by impoverished black people, who practice an ethnic religion. The distancing of the religious dimension and the valorisation of the ethnic characteristics of the Afro-Brazilian religions complexifies the boundaries of ethnicity, colour and class. For public policy managers, the affinity between terreiros, negritude and poverty is the element generating the public policy.

In the photos illustrating the official document, strategic use of a sepia tone masks the real skin colour of the people photographed. In the photos we see women, most middle-aged and older, wearing liturgical clothing from Afro-Brazilian religions, while the captions contain no mention of terreiro, referring instead to 'traditional territory.' The text of the document informs:

According to the research, $72 \%$ of lideranças tradicionais de matriz Africana 6 declared themselves to be black, while $55.6 \%$ are women. These figures confirm

6 Traditional leaders of African Origin is the name utilized to refer to Pais and Mães de Santo in the document. 
the active role played by black women in traditional African-origin communities in Brazil. At the same time, in Brazilian history from the sixteenth century to the present, black women have experienced the highest degree of social vulnerability. (Brazil 2013)

The notion of ethnicity in discussions of Afro-Brazilian religions was always perceived as a reference to Africa, almost invariably related to the skin colour of the worshippers concerned, who, mostly black, would explain all the discrimination suffered due to the racism permeating Brazilian society. Recent studies of the theme have shown that the equation Afro-Brazilian religions $=$ negritude $=$ discrimination contains a number of variables that cannot be so easily simplified.

The main such variable is the fluidity of the colour and class of those practicing this religion. Encountering followers of Afro-Brazilian religions among members of the São Paulo middle class (Prandi 2005: 247) or in the Southern Cone countries (Oro 1995) demonstrates the religion's potential to be incorporated into modernity as one more of the many religious alternatives to fragmentation and individualism.

Observing the expansion of Pentecostalism in Brazil over recent decades, some researchers have gone as far as to predict that the days of Afro-Brazilian religions are numbered:

Fragmented into small groups, weakened by the absence of a broader type of organization, having to carry the burden of racial prejudice which is transferred from the black person to black culture, the religion of the Orishas has little chance of beating the (unequal) competition with other religions. Silently, we are today witness to a true massacre of Afro-Brazilian religions. (Prandi 2005: 236).

While phenomena like the transnationalization of Afro-Brazilian religions seemed to deconstruct once and for all the link between terreiros, ethnicity and social marginality, the elaboration of a series of public reparation policies aimed at these groups has once again rebuilt connections between categories previously taken as disparate.

For these priests, the deterritorialization of Afro-Brazilian religion (Oro 2010) and of the circuits of activism themselves does not imply any loss of awareness of the ethnic dimension of their religiosity: on the contrary, it reinforces it. When they frequent forums and discussions on public policies 
for Afro-Brazilian religions, these religious leaders dialogue with intellectuals and high-ranking government officials, appropriating a discourse that they later reproduce among their peers: in this discourse terms like territoriality and ethnicity comprise key elements in the construction of a new identity.

In this process, skin colour is not the most important diacritical factor in the construction of a black identity. Traditional forms of organization, belonging to an ethic territory, memory and ancestrality, are all mobilized. Black identity is constructed in reference to Africa and negritude, something acquired from the moment of initiation into an Afro-Brazilian religion. By submitting to the criteria of hierarchy and ancestrality existing in the religion, the adherent becomes an African, irrespective of his or her colour, class or social background. It is through this connection that the adherent of Afro-Brazilian religions fights for rights in public spaces.

\section{Final Considerations}

The relation between religion and ethnicity in the context of AfroBrazilian religions in Brazil can be traced to the transformations undergone by these religions on Brazilian soil. When they arrived in Brazil, brought by enslaved Africans, these religions were a space of ethnic and cultural survival for these groups as distinct sectors of national society. After expanding greatly in the twentieth century, they adapted to urban ways of life, surpassing the boundaries of ethnicity, colour and social class.

For decades Afro-Brazilian religions were victims of intolerance on the part of public authorities and civil society. Today they benefit from the discourse of social inclusion present in modern Brazilian democracy in order to receive from the State public policies that assist in their survival and social reproduction. These public policies are based on the discursive construction of African-origin religions as spaces for maintaining civilzational values distinct from national society, brought from Africa by enslaved black people and kept alive by pais and mães de santo in contemporary Brazil.

The category Povos e Comunidades Tradicionais de Matriz Africana - elaborated in the dialogue between activists of Afro-Brazlian religions, academics and public policy managers - reaffirms the fundamental role played by religiosity in the construction of forms of resistance among Brazil's black population. The construction of public policies for this population by the 
federal government created a public grammar of social inclusion where the criteria of ethnic belonging that establishes a connection between terreiros, negritude and poverty is a fundamental part of the group's inclusion in the list of those ideally benefitting from these policies. Consequently the leaders of terreiros are broadening their notion of ethnic affiliation, claiming their own notions of ethnicity and territoriality as the main focal point of their identity construction.

Those who belong to Afro-Brazilian religions construct an ethnic identity containing religious and cultural values that are themselves based on a symbolic and discursive connection with Africa. One does not need to be an Afrodescendent to enter this symbolic universe: rather, the initiatory connection with the religion inserts the adherent within the circuit of African memory transmitted in conjunction with the ashe.

Afro-Brazilian religions today face persecution from neo-Pentecostals and, even though misunderstood and stigmatized by Brazilian society, are recognized as the legitimate heirs of traditional African knowledge by academics and public policy managers. It is in this intersection of discourses constructed in a political minefield that public policies for Afro-Brazilian religions are produced in contemporary Brazil.

Translated from the Portuguese by David Rodgers

Received December 28, 2013, approved May 14, 2014

\section{Bibliography}

ALMEIDA, Alfredo Wagner Berno de. 2002. "Os quilombos e as novas etnias". In: E. C. O’Dwyer (ed.), Quilombos: identidade étnica e territorialidade. Rio de Janeiro: Ed. FGV. pp. 43-81.

ALVES, Miriam Cristiane e SEMINOTTI, Nedio. 2009. “Atenção à saúde em uma comunidade tradicional de terreiro". Revista Saúde Pública, 43(1): 85-91.

ARABOMI, Tat'etu e SILVA, Roselane Andrea. 2011. "O axé entre as montanhas". In: BRAZIL. Alimento: Direito Sagrado. Pesquisa Socioeconômica e Cultural de Povos e Comunidades Tradicionais de Terreiros. Brasília: MDS, Secretaria de Avaliação e Gestão da Informação. pp. 83-84. 
BAKKE, Rachel. 2007. “Tem orixá no samba: Clara Nunes e a presença do candomblé e da umbanda na música popular brasileira”. Religião e Sociedade, 27(2): 85-113.

BARRETO FILHO, Henio Trindade. 2006. "Populações tradicionais: introdução à crítica da ecologia política de uma noção”. In: C. Adams, R. Murrieta, W. Neves (ed.), Sociedades caboclas amazônicas: modernidade e invisibilidade. São Paulo: Annablume. pp. 109-144.

BASTIDE, Roger. 2001. Os candomblés da Bahia. São Paulo: Companhia das Letras.

BRAZIL. 2006. Ministério do Desenvolvimento Social e Combate à Fome. Decree 6.040, $7^{\text {th }}$ February 2007. Institui a Política Nacional de Desenvolvimento Sustentável de Povos e Comunidades Tradicionais. BRAZIL. 2010a. Política Nacional de Saúde Integral da População Negra: uma política do SUS. Ministério da Saúde, Secretaria de Gestão Estratégica e Participativa, Departamento de Apoio à Gestão Participativa. Brasília: Editora do Ministério da Saúde.

BRAZIL. 2010b. Presidência da República. Casa Civil. Law n. 12288, $20^{\text {th }}$ July 2010. Institui o Estatuto da Igualdade Racial.

BRAZIL. 2011. Alimento: Direito Sagrado. Pesquisa Socioeconômica e Cultural de Povos e Comunidades Tradicionais de Terreiros. Brasília: MDS, Secretaria de Avaliação e gestão da Informação.

BRAZIL. 2012. Ministério de Desenvolvimento Social e Combate à Fome. "Governo vai lançar plano de Desenvolvimento para Comunidade de Matriz Africana”. Available at: <http:/www.mds.gov.br/saladeimprensa/ noticias/2012/agosto/governo-vai-lancar-plano-de-desenvolvimentopara-comunidades-de-matriz-africana/?searchterm=povos\%20de\%20 matriz\%20africana $>$. Accessed: $29^{\text {th }}$ January2013.

BRAZIL. 2013. Secretaria Especial de Promoção de Políticas de Igualdade

Racial. Plano Nacional de Desenvolvimento Sustentável dos Povose Comunidades Tradicionais de Matriz Africana.

CARVALHO, José Jorge. 2011. “A economia do axé: os terreiros da religião de matriz afro-brasileira como fonte de segurança alimentar e rede de circuitos econômicos e comunitários”. In: Alimento: Direito Sagrado. Pesquisa Socioeconomica e Cultural de Povos e Comunidades Tradicionais de Terreiros. Brasília: MDS, Secretaria de Avaliação e gestão da Informação. pp. 37-74. 
CORRÊA, Mariza. 1998. As ilusões da liberdade: a escola de Nina Rodrigues e a antropologia no Brasil. São Paulo: Edusp.

DANTAS, Beatriz Góes. 1988. Vovó Nagô e Papai Branco: usos e abusos da África no Brasil. Rio de Janeiro: Graal.

FIGUEIREDO, Aldrim Moura de. 2008. A Cidade dos Encantados: pajelanças, feitiçarias e religiões afro-brasileiras na Amazônia. Belém: EDUFPA.

HOBSBAWM, Eric e RANGER, Terence (eds.). 1992 [1983]. The invention of tradition. New York/Oakleigh, Australia: Cambridge University Press/ Canto.

LIMA, Márcia. 2010. "Desigualdades raciais e políticas públicas: ações afirmativas no governo Lula”. Novos Estudos CEBRAP, 87: 77-95.

LITTLE, Paul E. 2010. "A prática brasileira da ecologia política: aportes da antropologia”. In: C. B. Martins, L. F. D. Duarte (eds.), Horizontes das ciências sociais no Brasil, antropologia. São Paulo: ANPOCS. pp. 341-365.

MATORY, J. Lorand. 1999. “Jeje: repensando nações e transnacionalismo”. Mana. Estudos de Antropologia Social, 5(1): 57-80.

NALVA, Mãe e TAYANDÔ, Babá. “A voz do terreiro”. In: BRASIL. 2011. Alimento: Direito Sagrado. Pesquisa Socioeconômica e Cultural de Povos e Comunidades Tradicionais de Terreiros. Brasília: MDS, Secretaria de Avaliação e gestão da Informação. pp. 75-77.

O’DWYER, Eliane Cantarino. 2002. "Os quilombos e a prática profissional do antropólogo”. In: E. C. O’Dwyer (ed.), Quilombos, identidade étnica e territorialidade. Rio de Janeiro: Ed. FGV. pp. 13-42.

OLIVEIRA, João Pacheco de. 1998. Indigenismo e territorialização: poderes, rotinas e saberes coloniais no Brasil contemporâneo. Rio de Janeiro: Contra Capa Livraria.

ORO, Ari Pedro. 1995. "A desterritorialização das religiões afro-brasileiras”. Horizontes Antropológicos, 3: 69-79.

ORTIZ, Renato. 1978. A morte branca do feiticeiro negro. Umbanda: integração de uma religião numa sociedade de classes. Petrópolis: Vozes.

PRANDI, Reginaldo. 2005. Segredos guardados: orixás na alma brasileira. São Paulo: Companhia das Letras.

RODRIGUES, Raimundo Nina. 2004. Os africanos no Brasil. 8a .ed. Brasília: Ed. UnB.

RODRIGUES, Raimundo Nina. 2006. O animismo fetichista dos negros baianos. Rio de Janeiro: Fundação Biblioteca Nacional/ Editora UFRJ. 
SCHWARCZ, Lília Moritz. 1993. O espetáculo das raças: cientistas, instituições e questão racial no Brasil, 1870-1930. São Paulo: Companhia das Letras.

SILVA, José Marmo da. 2007. "Religiões e saúde: a experiência da Rede Nacional de Religiões Afro-Brasileiras e Saúde”. Saúde e Sociedade, 16(2): 171-177.

SILVA, Vagner Gonçalves da.1995. Orixás na metrópole. Petrópolis: Vozes. 